\title{
REPERFORMANCES AND THE TRANSMISSION OF TEXTS
}

'How authentic is the transmitted performance script in view of reperformances?' asks Martin Revermann at the start of the third chapter of his fundamental work

Comic Business. ${ }^{1}$ His immediate, wry response, 'only a classicist can come up with this sort of question', should not discourage us from continuing to ask it, especially as Revermann himself devotes considerable space to analysing its implications. For the texts of Greek tragedy, early reperformance was both a blessing and a curse. A blessing, because reperformance both manifested and encouraged the kind of popular interest without which these texts would not have survived. ${ }^{2}$ A curse, because reperformance is an essentially dynamic process, one in which the performers actively engage with the material that they are enacting, and make changes to it in order to suit their own (theatrical, financial, social, political) circumstances; some of these changes may go so far as to involve alteration to the texts that they were using.

The first performances, and the very earliest reperformances, of classical tragedy will usually have involved the poet who composed the work. Today the roles of playwright, director, and producer are separate and almost always undertaken by different people; in classical Greece, all these functions were played by the same man. In the early days of tragedy there was only one actor, the playwright himself. The origin of the professional actor lies in the decision, attributed to Aeschylus, to introduce the second actor, who ex hypothesi could not be played by the first

\footnotetext{
I am grateful to Professor David Kovacs for helpful comments.

${ }^{1}$ Revermann 2006, 66.

${ }^{2}$ See my chapter on Sophoclean reperformance above.
} 
actor/playwright; Sophocles is said to have introduced the third. ${ }^{3}$ The playwright continued to be one of the actors for a while; Sophocles is said to have been the first dramatist who recused himself from this role on the ground of his weak voice. ${ }^{4}$ Over time, however, the two roles separated thanks to growing specialisation; the qualities required to be a good writer of poetry only partly overlap with the qualities needed by a good actor, and a man who could devote himself to only one of these tasks was likely to produce work of a higher quality and thus attract greater appreciation from his audience. Whether he was acting or not, the playwright's pervasive involvement in the process of performance will have ensured his control over the texts that he had written. Even famous actors will presumably have had to deliver the exact words (mistakes apart) that the playwright intended them to say. ${ }^{5}$ There would be no question of their interfering with written texts of the plays, either; the master copies

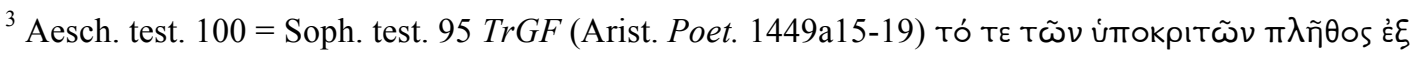

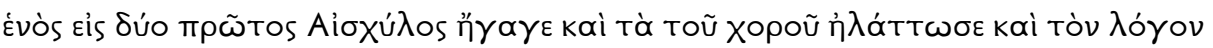

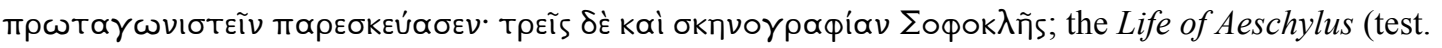
1.58-9) attributes the introduction of the third actor to Aeschylus. The tendency in ancient scholarship on tragedy to attribute developments to particular famous poets means that we cannot be certain that Aeschylus and Sophocles were responsible for these changes; but the pattern of development that they imply is likely to be real.

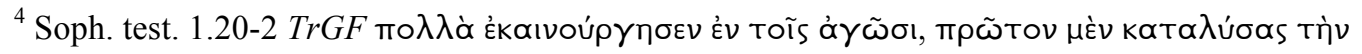

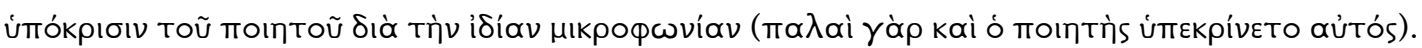
Again, we cannot rely on this anecdote for certain information about Sophocles, but the withdrawal of the tragic poet from acting in this period is likely to be accurate, not least as it is consistent with the growing importance won by actors throughout the fifth century and beyond, as discussed below.

${ }^{5}$ Dawe 2006, 18 goes a bit far when he writes that 'when it comes to the relationship between the text first written by Sophocles and the words spoken by the actors at the first or any subsequent performance, we know nothing', but his general note of caution is well taken and applies throughout this chapter. 
will have been held by the playwrights themselves. So the chance of errors creeping into the texts of tragedy thanks to these performances seems small.

However, these circumstances did not apply when the playwright was no longer involved in the direction and production of the performances. This was sometimes the case even in first performances, since a few plays, such as Pratinas' Perseus and Tantalus, Euripides' Iphigenia at Aulis, Alcmaeon in Corinth, and Bacchae, and Sophocles' Oedipus at Colonus had their premières after their respective playwrights' death. ${ }^{6}$ Tragic poets may not have been able to supervise every production of their plays even during their lifetimes, especially in the case of reperformances; they may have permitted others to direct their work, whether at the Rural Dionysia in Attica or elsewhere in Greek world. ${ }^{7}$ And where the poet was not involved in supervising the performance, there was the potential for alterations to the text to suit the specific circumstances of a given performance context. It is not impossible that playwrights themselves were complicit in this kind of textual alteration - if some foreign reperformance, say, demanded a somewhat shorter version of a given play than had originally been acted out at Athens, the playwright may well have been obliged to change his text in order to be able to put his play on at

\footnotetext{
${ }^{6}$ Pratinas: $\operatorname{Tr} G F$ I 4 T 2 (plays put on in 467 by his son Aristias); Euripides: $\operatorname{Tr} G F$ I DID C 22 (plays put on probably in 405, as Kovacs 200377 n. 4 argues, by his son or nephew Euripides the younger); Sophocles: $\operatorname{Tr} G F$ I DID C 23 (play put on in 401 by his grandson Sophocles).

${ }^{7}$ Sophocles and Euripides directed performances of their own plays at the Rural Dionysia, and Aeschylus and Euripides directed performances of their own plays abroad (see this volume, passim; my own other chapter looks at the evidence pertaining to Sophocles), but they were not necesssarily in a position to direct their own plays in these contexts on every occasion.
} 
all. $^{8}$ And once that change was made, there was nothing to stop the playwright from retaining the master script used for that reperformance as well as, or instead of, the script of the original first performance. ${ }^{9}$ This complicates the whole idea of what the 'original' text of a given play actually was. ${ }^{10}$

But usually the people who had the opportunity, and the motive, to make these alterations were the actors. Originally, as we have seen, actors and playwrights were one and the same, but in time poets were replaced by actors. How early this process must have begun is demonstrated by the introduction of a prize for actors at the Dionysia between 450 and $447 .^{11}$ This new award will not have come out of nowhere; it makes sense only in the context of a growing recognition that actors constituted a profession in their own right, and needed and deserved recognition for excellence just as the poets themselves did. The star actor, we may infer, was a phenomenon already in the first half of the fifth century. We know very little about individual actors from this century - unsurprisingly, since we know relatively little about the lives of even famous authors who lived in this period. But there is evidence that some were familiar figures in their own right. The actor Molon was well-known enough to have been

\footnotetext{
${ }^{8}$ Such a reworking (whether by the original author or by someone else) is called (at least in later

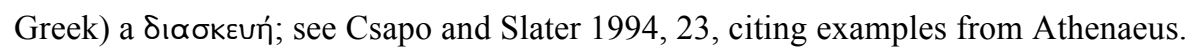

${ }^{9}$ A second performance, supervised by the original poet/director, has demonstrably affected the text of Aristophanes' Clouds and Frogs. It would be a brave scholar who asserted that this phenomenon has had no effect on our texts of tragedy.

${ }^{10}$ Cf. Sir Tom Stoppard's remarks (cited by Dawe 2006, 17-18) on the complex relationship between the dramatist and his text even in the earliest stages of its composition.

${ }^{11}$ The first extant prizewinning actor in the Fasti is recorded for the year 447 ( $\operatorname{Tr} G F$ I DID A 1.70); analysis of the inscription reveals that the first such record could not be earlier than 450 (thus Millis and Olson 2012, 11-12).
} 
satirised by Aristophanes in $405 .^{12}$ A mistake in pronunciation led to Hegelochus, protagonist in Euripides' Orestes in 408, to be mocked three years later by Aristophanes, and also by Strattis and Sannyrion. ${ }^{13}$ For the comic poets, tragic actors were no mere faceless interpreters of other people's work, but prominent individuals famous enough to be mocked by name.

The prestigious status acquired by actors in Athens was confirmed in 386, when reperformance of tragedy became part of the City Dionysia for the first time. ${ }^{14}$ It is not always sufficiently emphasised that this innovation is explicitly said to be the result of initiative by actors. ${ }^{15}$ Reperformance was a phenomenon in which they had a particular stake. As described above, it gave them greater freedom to innovate than would be the case in a first performance supervised by the poet who had written the play. ${ }^{16}$ It also allowed them to build up a repertoire of parts for which they were particularly famous; they could win a reputation for playing (say) Ajax in Sophocles'

\footnotetext{
${ }^{12}$ Eur. test. $69 \operatorname{Tr} G F$ (Ar. Ran. 55). The identity of Molon as a tragic actor is given by the Aristophanic scholia, not by the text of Aristophanes itself (although the text at that point is concerned with tragedy, since Dionysus has just referred to reading Andromeda, and this may mean that Molon was the protagonist of that play in 411, as O'Connor 1908, 117 suggests). But we can be fairly sure that the scholia are right because Demosthenes refers to Molon as a famous actor of the old school (19.246) unless the scholia are guessing on the basis of this passage of Demosthenes.

${ }^{13}$ Eur. test. 67b $\operatorname{Tr} G F$ (Ar. Ran. 303-4), test. 67a (Strattis frr. 1, $63 P C G$ ), Sannyrion fr. 8 PCG.

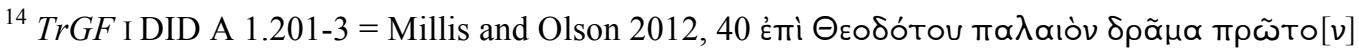

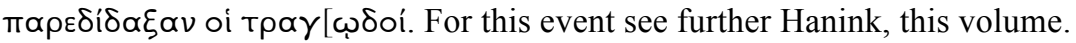

${ }^{15}$ See further the discussion in my other chapter.

${ }^{16}$ Under fourth-century conditions, however, where according to Aristotle the actors had greater power

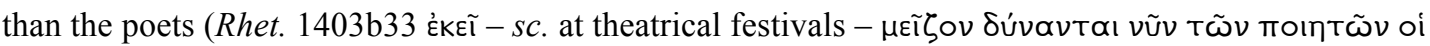
úmokpıт $\alpha i$ ), even a poet supervising a performance might have trouble holding his own against the actors.
} 
play, ${ }^{17}$ or Electra in Euripides', learning the role through repeated reperformances, and attracting more spectators who wanted to see the star in a given role. The very decision by the actors to offer tragic reperformance at the festival, however this offer was actually managed, suggests a feeling of corporate identity which again is the consequence of a growing sense of professionalism.

Just as the introduction of a prize for actors implies a long-term development in the idea of what it meant to be an actor, so too the introduction of reperformance at the Dionysia is not something wholly new, but part of a longstanding trend. Reperformance was already a feature of the Rural Dionysia, and individual plays were being put on again outside Attica. The evidence of vases in particular suggests widespread reperformance of tragedy in the Greek west, Italy and Sicily, from at least the beginning of the fourth century. ${ }^{18}$ Such reperformances, especially those put on outside Athens itself, will not have been exact copies of the original Athenian productions. Local circumstances, and the desire by actors to reshape plays to emphasise their own artistic ability, will have led to all kinds of changes, and there is no reason to think that the script was singled out for special protection.

This, then, was the fourth-century context: a world in which, it seems, the original texts of fifth-century tragedy could scarcely be preserved unaffected by both the greater importance of the acting profession and the increasing phenomenon of reperformance. With these considerations in mind, Revermann asks 'How can we be sure that our text of, for instance, Euripides' Troades represents the script of the

\footnotetext{
${ }^{17} \mathrm{Cf}$. Timotheus of Zacynthus, an actor of uncertain date whose nickname $\Sigma$ фq $\gamma \varepsilon \cup$ s, 'the slayer', derived from his fame for delivering Ajax's suicide $(\Sigma 864 \mathrm{a}=$ p. 195 Christodoulou $)$.

${ }^{18}$ See Taplin 2007. This evidence needs to be treated with care (see Coo 2013 for the particular difficulties involved), but not even the most extreme sceptics deny any connexion between at least some vases and reperformance of Attic drama.
} 
original performance at Athens in 415 and not, say, a performance at Thurioi in $350 ?{ }^{19}$ His question follows a discussion of the equivalent problem for comedy, in which he argues that the topical allusions to particular details of contemporary fifthcentury affairs in the transmitted texts of Aristophanes' plays make plausible a working hypothesis that these plays largely correspond to the first performances at the great Athenian festivals. ${ }^{20}$ Such localised allusions constitute the kind of material that would have been removed if there had been large-scale reworking of Aristophanes' plays for reperformance, as often happens today when the political references in these dramas are updated for modern audiences; since it has not been removed, we may provisionally conclude that there has been no large-scale reworking. In the case of tragedy, on the other hand, there were virtually no such allusions in the first place, ${ }^{21}$ and so usually we cannot point to any basic core that absolutely must be from fifthcentury Athens. That is what leads to Revermann's pessimistic conclusion, that 'nonauthorial interpolations by subsequent producers and scholars have demonstrably left their vestiges in our texts ... [and] many changes may not be detectable any longer

\footnotetext{
${ }^{19}$ Revermann 2006, 81.

${ }^{20}$ Ibid. $78-81$.

${ }^{21}$ There is a slight danger of circular argumentation here, since our picture of what fifth-century tragedy did or did not contain is largely dependent on the texts whose authenticity is the point under discussion. But if such allusions were present in the original scripts in any number, it would have taken a prodigious amount of reworking to reduce them to what we find there now. There are many jokes in Aristophanes that we cannot now understand because we do not know the often transient circumstances that lay behind them; there are no passages in tragedy which require such additional parochial information for their comprehension (even if appreciation of a very few, such as the account of the founding of the Areopagus in Aeschylus' Eumenides, can be heightened thereby).
} 
by critical analysis. It is for this reason that I am more hesitant in endorsing the authenticity assumption as a working hypothesis for tragedy than I am for comedy'. ${ }^{22}$

The hypothesis that actors in particular changed the texts of the plays that they reperformed, and that their texts influenced the tradition that reached Alexandria and, from there, reached us, is a mainstay of modern scholarship. ${ }^{23}$ But it is no modern conjecture without a basis in ancient evidence. Several times the ancient commentators on tragedy record textual disputes in which actors are blamed for introducing erroneous readings into the original. It may be helpful to gather these passages together for consideration:

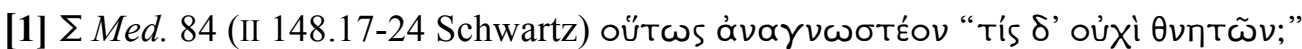

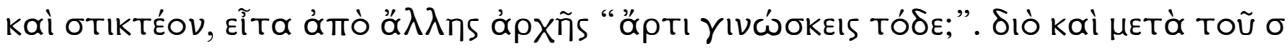

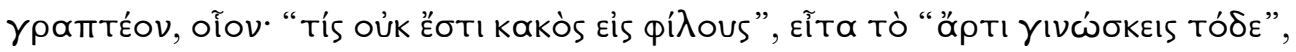

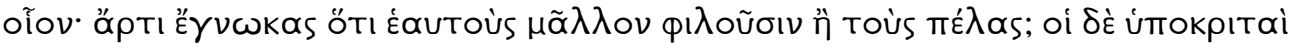

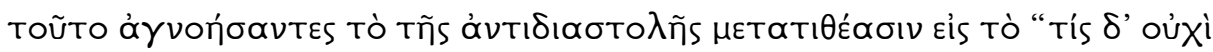

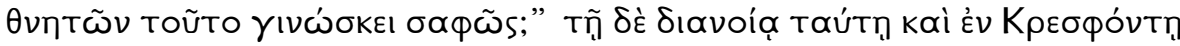

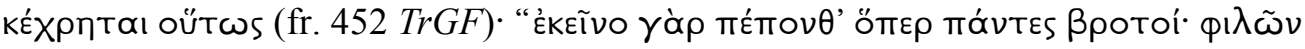

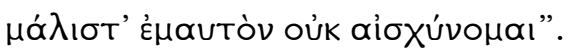

\footnotetext{
${ }^{22}$ Revermann 2006, 83.

${ }^{23}$ For recent discussion of the phenomenon, with references to earlier work, Revermann 2006, 76-83, Scodel 2007, 142-7, Allan 2008, 83 n. 372, Vahtikari 2014, 54-8. Finglass 2006 postulates that curses in ancient drama were particularly liable to be expanded by interpolation, and refers several times to actors as a likely source of that interpolation. Among older studies Page 1934 is a classic, but puts excessive faith in the scholia (analysed below); discussion of the phenomenon by other scholars has sometimes suffered because Page's famous work is often the only one to which they refer. The best and most accessible discussion is still that of Hamilton 1974, which combines an excellent survey of past scholarship with an appropriately sceptical analysis of the external evidence; see also Falkner 2002.
} 
The correct reading is 'Who among mortals [sc. does not do that]?', with punctuation following, and then, from a new beginning, 'Have you only just realised that?'. As a

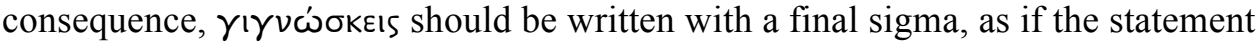
'Who isn't bad towards his friends?' were followed by 'Have you only just realised that?', in the sense of 'Have you only just realised that people love themselves more than they do their neighbours?' But the actors failed to realise this and removed the punctuation between the phrases, giving 'Who among mortals does not know that for sure?' He makes use of the same idea in Cresphontes, as follows: 'My experience is the same as that of all mortals; I am not ashamed to love myself best.'

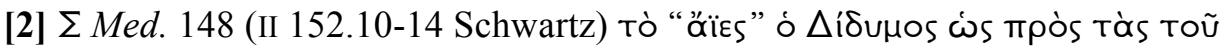

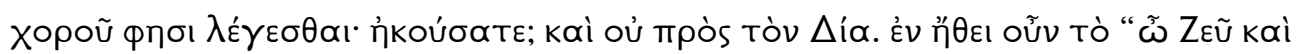

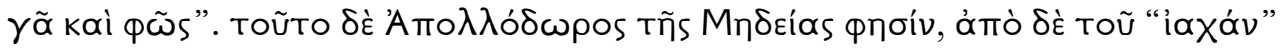

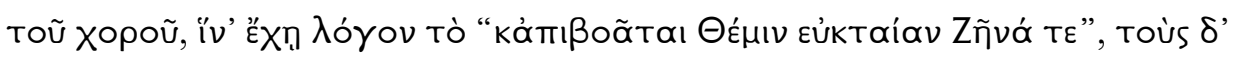

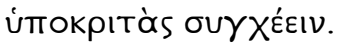

Didymus says that the word ơï̌s is spoken to the women of the chorus and means 'did you (plural) hear', and is not spoken to Zeus. The expression 'O Zeus, earth, and light' is in character. But Apollodorus says that it belongs to Medea, and that the chorus's part begins with the word iaxóv, so that the expression 'and she invokes Themis who is addressed in prayer, and Zeus' makes sense; but that the actors confused the matter.

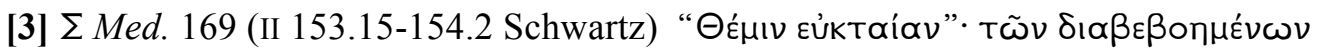

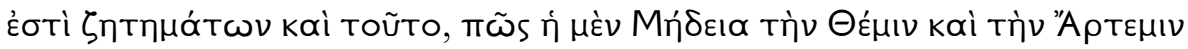

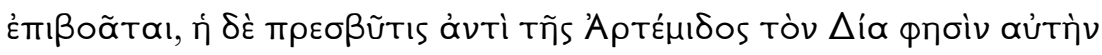

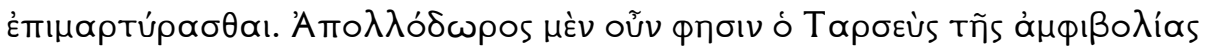




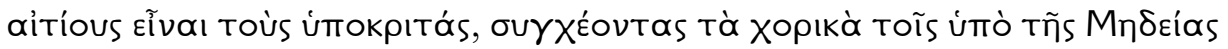
$\lambda \varepsilon \gamma o \mu \varepsilon^{\prime}$ oIs.

'Themis who is invoked in prayer'. This, too, is one of the most notorious problems how it is that Medea cries out to Themis and Artemis, whereas the old woman says that she calls to witness Zeus instead of Artemis. Apollodorus of Tarsus says that the actors are responsible for the ambiguity, in that they confused the choral passages with the lines delivered by Medea.' [There follows a textual point concerning the attribution of lines.]

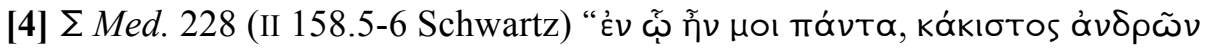

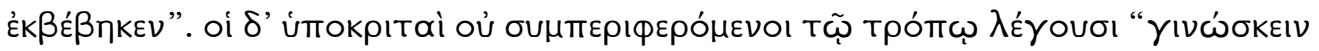

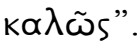

'The man in whom my whole existence was bound up has turned out to be the worst of men'. But the actors, who are not conversant with the style, say, 'to know well'.

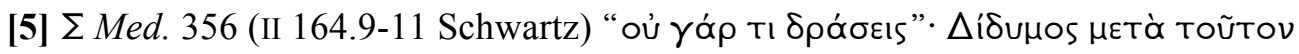

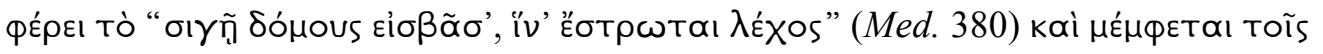

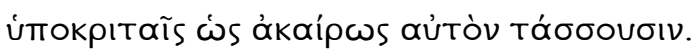

'For you will not do anything'. After this line Didymus puts the line 'going up to the house in silence, where her bed was spread', and blames the actors for putting it in the wrong order.

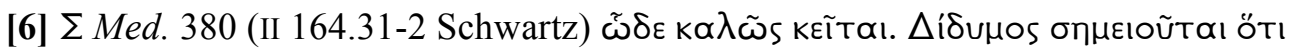

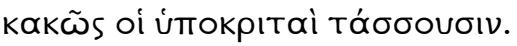


This is the correct place. Didymus indicates that the actors put the line in the wrong position.

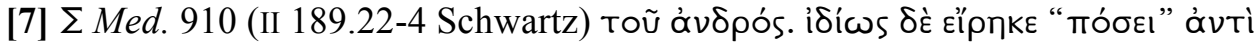

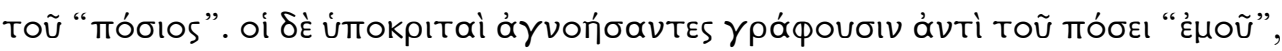

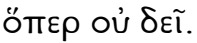

'Of her husband'. In accordance with an idiosyncratic usage, he says móoєı instead of

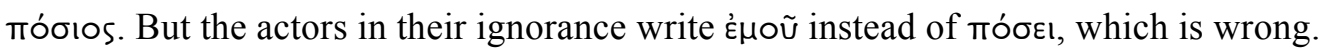

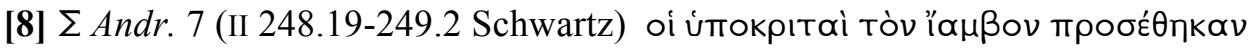

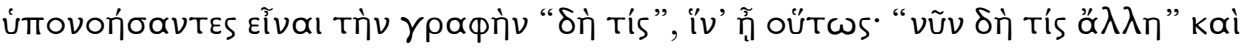

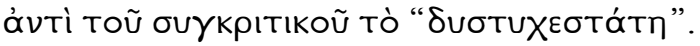

The actors add this line as they suppose that the text [of line 6] reads $\delta$ ì Tís, so that it runs as follows: "Now what other women is most wretched" (that last word being used in place of a comparative).

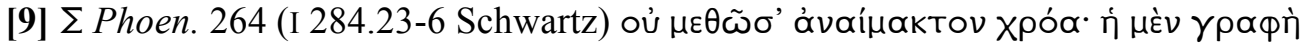

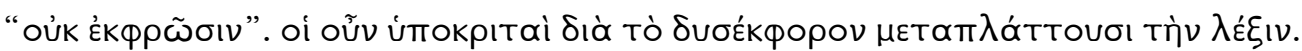

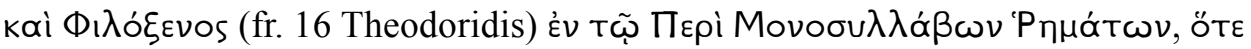

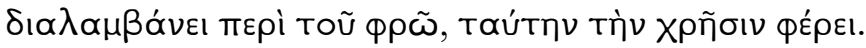

'May not allow out ( $\mu \varepsilon \theta \tilde{\omega} \sigma$ ') my skin unbloodied'. The text reads 'may not let out'

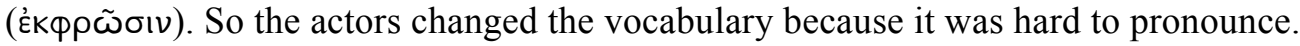
And Philoxenus in his book on monosyllabic words, when he treats the subject of the word $ф \rho \tilde{\omega}$, makes use of this example. 


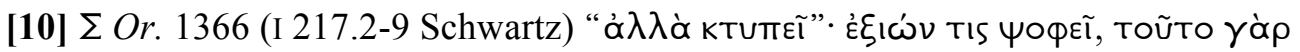

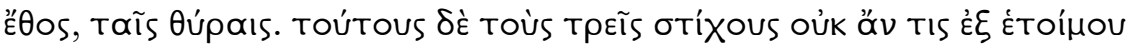

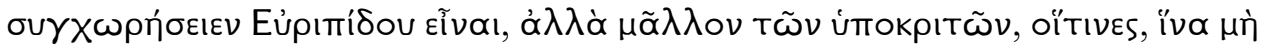

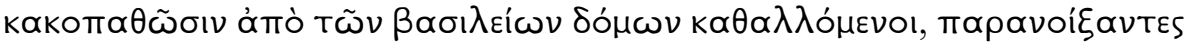

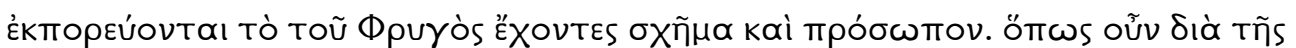

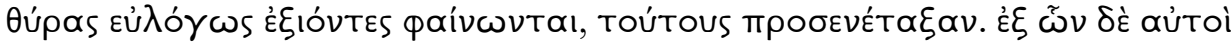

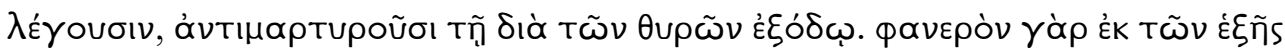

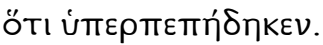

'But there is a noise ...' Someone makes a sound with the doors while going out, since that is the custom. One would not readily agree that these three lines belong to Euripides, but rather to the actors, who, so that they would not come to harm by jumping down from the palace, set the door ajar and come out wearing the costume and mask of the Phrygian. And so, in order that it would seem reasonable for them to go out via the door, they added these lines. But from the words that they themselves say, they bear witness against the exit via the doors. For it is clear from the passage to come that he has jumped.'

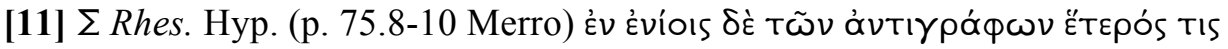

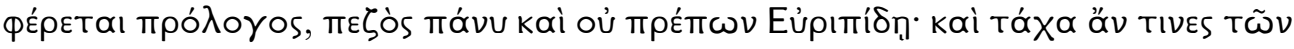

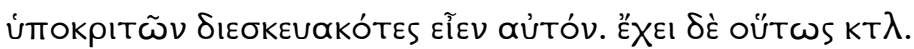

In some copies there is a second prologue, which is extremely pedestrian and not appropriate to Euripides. It may well represent a revision by certain actors. It goes like this [11 trimeters follow].

One question keeps arising as we consider these ancient comments: how did the scholars in question know that actors had tampered with the text? It is theoretically 
possible that they had got hold of different copies of a given play, identified one as an actor's text, and noted differences between it and some other copy that they were certain was not an actor's text. But we may wonder how common this procedure was, if indeed it ever took place. Did ancient scholars engage in this kind of research? Consideration of individual passages does nothing to support that idea that this was actually what happened.

In passage [9], for example, actors are said to have written $\mu \varepsilon \theta \tilde{\omega} \sigma^{\prime}$ instead of

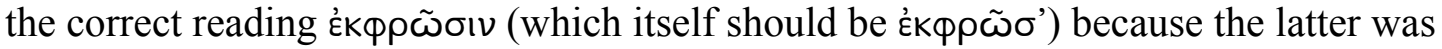

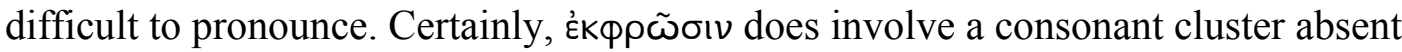
from $\mu \varepsilon \theta \tilde{\omega} \sigma^{\prime}$, but an actor who found it so tricky to pronounce that he needed to change the word was probably in the wrong profession to begin with. ${ }^{24}$ Even if we suppose, for the sake of argument, that this actually happened - how is the scholar meant to have found this out? A putative actor's copy will not have included a marginal note explaining why there was a difference in this line from the text found in other manuscripts. It looks like a guess on both counts - both the attribution to actors, and the explanation that the change resulted from problems of pronounciation. The actual error, however, is plausible; the correct reading was apparently known to Philoxenus (of Alexandria, first century BC). As Mastronarde comments, it involves the 'simple substitution of a more familiar word. That actors made the change $\ldots$ is strongly to be doubted' ${ }^{25}$ Any transcriber could mistakenly have written $\mu \varepsilon \theta \tilde{\omega} \sigma$ '

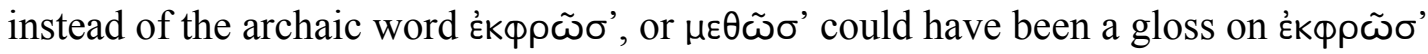

\footnotetext{
${ }^{24}$ Might the famous story of Hegelochus' mistake (cited above) lie behind this remark? The story could have suggested that actors were keen to remove anything from their texts that could cause them problems and consequent humiliation.

${ }^{25}$ Mastronarde 1994, ad loc.
} 
which was wrongly promoted to the text. Unintentional error is vastly more likely here than calculated histrionic change.

Passage [1] shows a textual error resulting from the failure to appreciate a sense pause in the middle of a line; such mistakes were easy at a time when written punctuation did not exist. The blame is ascribed to actors, but there is no reason to think that they were especially liable to be at fault here. Someone delivering the line aloud might indeed have been in a better position to realise where the pause lay than a reader would. Even if an actor had been responsible, it is hard to see how this fact could have been recorded. It looks like the scholar who wrote this note is casting around for someone to blame, and chooses the actors.

Passages [2] and [3] relate to what was evidently an ancient scholarly

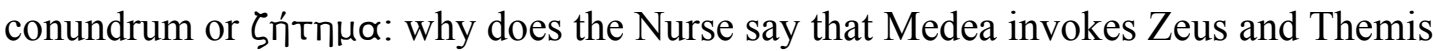
when, according to our texts, she never invokes Zeus by name? One solution to this apparent problem, advocated by Apollodorus of Tarsus, was to attribute line 148 to Medea instead of to the chorus - in fact this is impossible, since it would upset the responsion between strophe and antistrophe. ${ }^{26}$ Apollodorus attributes the alleged confusion of lines to actors. Since the alleged confusion never took place, actors were not at fault here. Moreover, this kind of confusion is precisely the sort that would be least likely to occur in performance, where the balance between strophe and antistrophe would be immediately apparent to actors and audience alike. That kind of

\footnotetext{
${ }^{26}$ For the question of speaker responsion in such lyric dialogues see Finglass 2009, 5-8 and 2011, on Soph. Aj. 371. The likely solution is offered by Page 1938, 80: ‘since Medea complained about Jason's oaths [in 161-2] the Nurse is quite justified in calling this an appeal to Zeus, as long as she defines

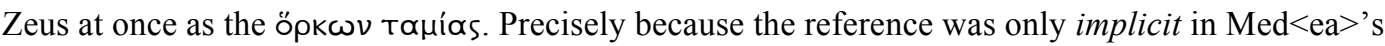
words, the Nurse here adds the title and definition explicitly'.
} 
mistake would occur far more readily in the context of transcribing a text, since it would involve the shift of a mere paragraphos. ${ }^{27}$

In [5] and [6] we are dealing with a related issue, the order of verses: according to Didymus, the actors placed line 380 after line 356 . But the line makes no sense in that position, as would have been clear in rehearsal to any actors who tried it, let alone in an actual performance. By contrast, the miswriting of a line in the wrong place can be easily caused by the scribe's eye jumping to the wrong column. The textual issue is complicated by the almost exact equivalence of $379-80$ to lines $40-1,{ }^{28}$ but whatever the correct solution of this problem is, it is apparent that actors cannot be responsible for what Didymus accuses them of.

[4] and [7] involve slight changes to individual words or phrases, [8] the addition of a line and consequent minor change of text in the previous line. All seem standard textual errors; there is nothing in them that looks intrinisically histrionic. In [4], in particular, the text attributed to the actors is senseless; once again, we can rule out the hypothesis that actors would have made a change to the text that would have made them seem ridiculous. [11] involves an alternative prologue for the Rhesus, which the scholia attribute to actors; this is at least a possible hypothesis, although since the other references to actors in the scholia seem just guesses, there is at least a presumption that this is a guess too. And the highly tentative language of the

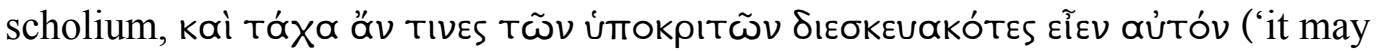
well represent a revision by certain actors.') indicates that this presumption is likely to be right.

\footnotetext{
${ }^{27}$ For textual errors involving the movement of a paragraphos seem Finglass 2014b.

${ }^{28}$ For a discussion of the whole question see Willink $1988=2010,116-31$.
} 
Perhaps the most interesting of the above extracts is [10]. One passage from the transmitted text of Euripides' Orestes implies that the Phrygian slave enters via the skene door (1366-8), another that he comes down from the roof (1369-74). A scholar has evidently noted the apparent inconsistency, diagnosed corruption, and come up with a plausible hypothesis to explain that corruption; namely, that lines $1366-8$ were added by actors to facilitate the staging. Here, at least, the interference attributed to actors is in a theatrical context and aimed at a plausible dramaturgical goal. But it is by no means clear that the transmitted text does require the Phrygian to come down

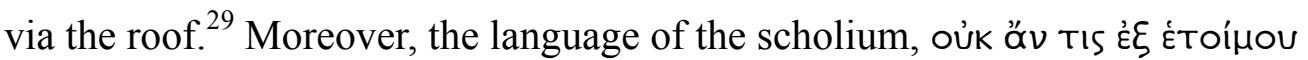

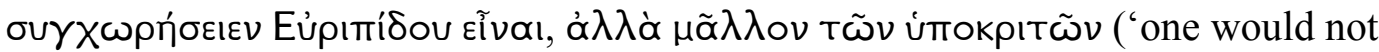
readily agree that these three lines belong to Euripides, but rather to the actors'), strongly suggests that even this hypothesis is merely a guess. ${ }^{30}$

Repeatedly these scholia seem quite unreliable in their claims about ancient actors' interference in the texts of tragedy. It is not just a matter of wondering how the ancient commentators got this information about the actors; rather, many of the errors attributed to actors seem precisely the sort of mistakes that performance would reveal and root out, not changes made in the hope of improving a text for the stage. As Zuntz says, 'here [i.e. passage [6]] . . "the actors" were, to Didymus, mere whipping-boys suited to take the blame for what he, wrongly, regarded as a fault. This instance inclines one to apply the same diagnosis to other similar passages'. ${ }^{31}$

So the remarks of ancient scholars concerning the textual intervention of

\footnotetext{
${ }^{29}$ Both Willink 1986 and West 1987 keep all the lines (although West suggests that 1366 alone may be a later addition), the former arguing (on 1370-2) that 1369-74 do not imply an entry via the roof.

${ }^{30}$ Thus Hamilton 1974, 396-7.

${ }^{31}$ Zuntz 1965, 254 n. $\dagger$.
} 
actors in certain passages of tragedy cannot be relied upon. But it does not follow that there were no such interventions. We can argue this in part, as above, on the basis of general probability. Actors will have done everything possible, including changing the text of previously performed plays, to make their performances as effective as they could; they had no interest in maintaining any particular text as somehow canonical. We can also argue on the basis of other, more reliable information transmitted about ancient actors. So Aristotle tells us that Theodorus was particularly keen on always delivering the opening lines of a play; ${ }^{32}$ and as Hamilton points out, 'if the protagonist is to speak the first words in every play, this would often mean considerable relocation and adaptation of the original', ${ }^{33}$ since the opening speaker of many plays is not in fact the protagonist. And we can argue on the basis of a firm historical datum: the creation, in the 330s, by the Athenian statesman Lycurgus, of a state archive of texts of the tragedians, which the city scribe was to read to the actors, who were not permitted to act from any other text. ${ }^{34}$ In Scodel's words, these were 'at

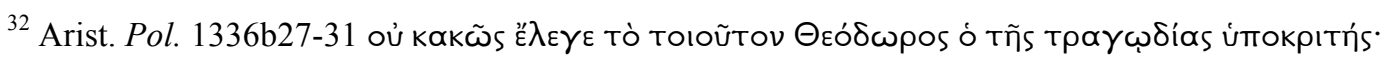

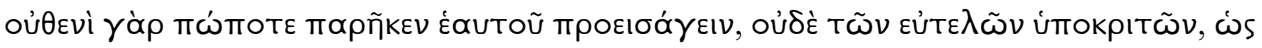

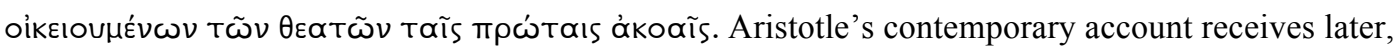
independent, confirmation from Plut. Quaest. Conv. 737ab, an anecdote concerning Theodorus which has as its punchline the opening line of Sophocles' Electra (i.e. line 2 in our numeration, since line [1] is probably spurious: see Finglass 2007 ad loc.).

${ }^{33}$ Hamilton 1974, 401. So also Hall 2010, 161: 'since Theodoros specialized in reviving canonical masterpieces by Sophokles and Euripides, this must in practice have meant that new prologues needed to be created hastily and prefixed to favourite plays in the repertoire'.

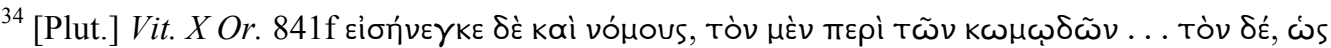

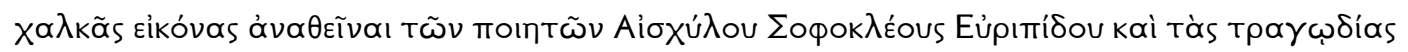

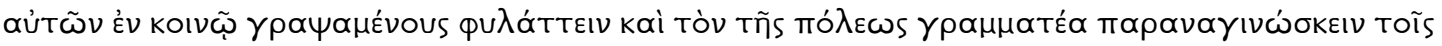

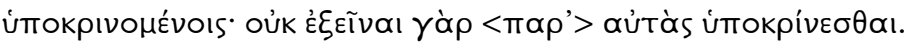


once talismanic, not entirely unlike the statues of the tragedians that Lycurgus also had erected, and practical, placing a genuine limit on the freedom of actors to transform texts at the festival that claimed to be the most authentic home of tragic performance'. ${ }^{35}$ Such a regulation only makes sense if actors had been using a range of different texts of (at least) the three great tragedians, and if this was perceived as a problem.

In Hamilton's view, Lycurgus' law 'assumes the existence of a "clean” copy of the plays and gives no reason to suppose that such a copy would be obtained only with difficulty,. ${ }^{36}$ But this is altogether too charitable a view of fourth-century attitudes to textual criticism. Nearly two thousand years later, despite all the developments in scholarship that had taken place in the interval, Renaissance scholars showed surprisingly little care in the selection of the manuscript which formed the basis for their printed editions. So with Sophocles, for example, the editions of Turnebus (1552) and Stephanus (1568) were based on a manuscript heavily altered by the editorial activity of the Byzantine scholar Triclinius; the scholia to that manuscript would have made this clear to both scholars, yet they nevertheless adopted it as the foundation for their text, and were followed in this by all subsequent editors for over two hundred years before Brunck broke away from this tradition and set the foundation for all subsequent work on Sophocles in his great edition of $1786 .{ }^{37} \mathrm{We}$ should not expect a greater level of scholarly acumen in Lycurgus, or in whatever functionary was instructed to acquire a text of the tragedians for the state archive. ${ }^{38}$

\footnotetext{
${ }^{35}$ Scodel 2007, 152.

${ }^{36}$ Hamilton 1974, 401.

${ }^{37}$ See Finglass 2012, 16-17.

${ }^{38}$ Cf. Barrett 1964, 47: Lycurgus' text 'is likely to have been no more than an ordinary text of its day, carrying most of the modifications established by actors during the preceding century'.
} 
Moreover, the Lycurgan building project hints that he was not overly concerned with preserving the original fifth-century performance context for these plays; his interests were hardly aligned with those of the modern scholar. ${ }^{39}$ His official text may have made a contribution to preserving these tragedies accurately, not least if it was acquired by one of the Ptolemies, as we may infer from a passage of Galen, ${ }^{40}$ and was used as a master text in the Library of Alexandria. Nevertheless, there is no reason to think that Lycurgus' text itself was free from textual error, and as a result we are confronted by 'that fatal gap between the time of Sophocles himself and the first official transcript' ${ }^{41}$

Granted that actors did change texts, how if at all did these changes get into the textual tradition which has come down to us? Years ago, Hamilton suggested that 'the actual form of actors' texts may well have been unsuited to reading, ${ }^{42}$ and thus that stage texts were unlikely to have been the main conduit for the transmission to Alexandria and beyond. Since Hamilton wrote, a papyrus of Euripides' Alcestis, P.Oxy 4546, has been discovered, which is almost certainly an actor's copy; it contains only the lines delivered by the character Admetus. ${ }^{43}$ We may guess that most

\footnotetext{
${ }^{39} \mathrm{Cf}$. Finglass 2012, 11: 'his rebuilding of the theater in stone suggests that, for him, permanence trumped historical accuracy'.

${ }^{40}$ Galen, Commentary on the Epidemics of Hippocrates 2.4 (Soph. test. $157 \mathrm{Tr} G F$ ). The Ptolemy in question is probably Ptolemy III Euergetes (246-221); 'our source does not specify that these were the Lycurgan recension (referring simply to tò $\beta ı \beta \lambda i ́ \alpha$ - "the books", or perhaps "the famous books"), but it is a plausible assumption that they were' (Finglass 2012, 12). See Handis 2013 for a sceptical account of this story.

${ }^{41}$ Dawe 2006, 19.

${ }^{42}$ Hamilton 1974, 392.

${ }^{43}$ For this papyrus see Marshall 2004, Revermann 2006, 88-91.
} 
actors' copies were in this format, perhaps with the addition of some prompts; ${ }^{44}$ certainly, there was no need for an actor to have a text with the entire play transcribed. Director's copies, by contrast, will have contained compete works. We can identify several papyri that may fall into this category, since in place of character names they use a distinctive notation to indicate the speaker of each line: alpha, beta, and gamma, often surmounted by a horizontal stroke to indicate an ordinal number. Such notation is obviously useful in a theatrical context, in that it allows the director to see the entirety of a given actor's role (which will usually have encompassed more than one speaking character) across a single play. ${ }^{45}$ So if we are to think of theatrical texts of a play affecting the transmission of the text, it may be more helpful to speak about directors' copies rather than actors' copies.

Yet those directors' copies would not on the whole contain the kind of slight textual changes introduced by the actors in the course of improvisation. ${ }^{46}$ Certainly, some improvisations may have been so impressive that a director inserted them into his copy; but in general they will have been as transient as a given performance. What would have an impact on directors' texts is the kind of large-scale change - extra lines for the speeches to be delivered by the protagonist, for example, or a changed ending to give a different version of the myth - that would have to be inserted into the master

\footnotetext{
44 'An actor might be expected to want his interlocutor's words as well as his own to provide cues, but copying by hand is an irksome business, and ancient actors may well have been prepared to tolerate some inconvenience in order to avoid it as far as possible' (Parker (2007) lx).

${ }^{45}$ See Finglass 2014a, 77-9. Two of the relevant papyri contain tragedies, both by Euripides: P.Oxy. 2458 (Cresphontes) and 5131 (Ino). In the latter this notation is written in a different ink from the main text, and in addition to the names of the characters; this suggests a copy not originally intended for theatrical performance.

${ }^{46}$ Cf. Revermann 2006, 84-5.
} 
script, and thence into the actors' copies, since it was too extensive to be merely improvised. ${ }^{47}$ If an adaptation of an old classic proved popular, there would no doubt have been demand for that particular script from readers and other producers, and so the director's copy could have had an impact on the book trade. ${ }^{48}$ There would have been more than one version of each play in circulation, especially of the most popular ones; fourth century texts of tragedy are likely to have offered quite diverse texts of individual plays. Which copies were chosen for the Lycurgan text, and which made it to Alexandria, was a matter of luck.

With the exception of passage [11] above (the alternative Rhesus prologue), and perhaps [10] too (the alleged interpolation of three lines in Orestes), none of the passages in the scholia corresponds to this type of change. But it is not hard to think of possible examples. The text of Aeschylus' Seven Against Thebes is commonly thought to have been substantially altered during the fourth century under the influence of Sophocles' Antigone and Euripides' Phoenissae. ${ }^{49}$ Many of the interpolations in Euripides' Phoenissae, 'a text' according to Hall, 'that shows a high degree of adaptation and editing in the interests of reperformance, ${ }^{50}$ might also be the result of directorial intervention. A distinguished recent editor of the whole of

\footnotetext{
${ }^{47}$ Just because these large-scale alterations were recorded in directors' copies does not mean that actors were not involved. An individual actor could have made his preferences clear to his director, or presented him with the part that he was used to playing and required him to draw up a script that contained it

${ }^{48}$ For books in the fourth century see Pinto (2013).

${ }^{49}$ See Hutchinson 1985 on Aesch. Sept. [1005-78]. For the language of the final section see Barrett $2007,322-50$, a paper written in the late 1970 s or early 1980 s.

${ }^{50}$ Hall 2007, 280. For the most recent discussion of the textual problems surrounding Phoenissae see Lamari 2010, 205-7, with references to earlier literature.
} 
Euripides has recently suggested that our text of Orestes contains interpolations which he dates to some time after 356, arguing that they are inconsistent with politics at Delphi before that date; the interpolations were quite possibly inserted by the actor Neoptolemus for his revival of the play at the City Dionysia in $340 .^{51}$ The same actor may have been responsible for revisions to the Iphigenia at Aulis (a play almost universally recognised as having been interpolated, during more than one period), since he revived an Iphigenia play by Euripides at the same festival in $341 .^{52}$

If we are correct in identifying this phenomenon, it is likely that there will be examples which we cannot now discern. After all, actors and/or directors will not have gone out of their way to introduce inconsistencies, and without inconsistencies to help us we will find it hard to detect insertions. These people were also writing at such an early period that they are not likely to have made serious linguistic mistakes of the sort which can betray a later interpolator; nevertheless, sometimes there will be signs that we can detect. ${ }^{53}$ Similarly with the deletion of passages by actors and directors; it can be done in such a way that it is very difficult to work out that something is missing, and the actors and/or directors will have been aiming to do exactly that so that their audience would not be disconcerted. With later textual changes, the evidence of papyri can help; there are lines which no-one ever suspected were interpolated until ancient manuscripts were discovered which omitted them, and

\footnotetext{
${ }^{51}$ See Kovacs 2007.

${ }^{52}$ Kovacs 2007, 269 n. 13, referring to Kovacs 2003.

${ }^{53}$ Cf. Barrett (2007) 323 (written not long after 1978), of the person who wrote the conclusion of Aeschylus' Seven Against Thebes found in our manuscripts: 'his linguistic incompetence will manifest itself not in solecisms but in straining the language in what he mistakenly supposes to be the mannter of Aeschylus, or in falling flat where Aeschylus would have risen; and to demonstrate that kind of incompetence, to a reader who is predisposed to be deluded, will seldom if ever be possible'.
} 
scholars subsequently concluded that they were indeed later additions. ${ }^{54}$ But papyri will not help us to discover textual changes made in the fifth and fourth centuries; and the biggest deviations from the original scripts may be the hardest to detect. ${ }^{55}$

This volume is a welcome investigation into an aspect of the ancient theatre that has not always attracted the attention that it deserves. The early reperformance of tragedy proves the capacity of that genre to move audiences beyond the limits of time and space imposed by a single production; it demonstrates its cultural significance, its potential malleability, and the breadth of its appeal. The fact that reperformance may have affected the text even in the lifetime of the original author, sometimes at the hands of that author, complicates the idea of getting back to an 'original' text, and encourages us not to fetishise the first performance as if that were the only thing that mattered. For all that, it remains entirely legitimate to ask 'what happened at the original performance of this play?' or 'what did the author of this play actually write?'; and while subsequent reperformance has facilitated the transmission of something like the original text of a given drama down to our own day, it is also often responsible for changes to that text, many of which we are probably not in a position to detect, for all the successes of textual criticism over the last seven hundred years or so. Investigating the mutual relationship of reperformance and the transmission of texts should not force us to choose between either attempting to get as close as possible to the author's text, or appreciating the social and cultural circumstances which led to the adaptation of these texts in the decades that followed. They are both

\footnotetext{
${ }^{54}$ E.g. Soph. OR [531] (on which see Finglass 2013, 38-9, 2016, forthcoming) and Eur. Phoen. [1-2] (on which see Finglass 2007 on Soph. El. [1]; contra Meccariello 2014).

${ }^{55}$ In the memorable words of Dawe 2006, 19, 'the modern textual critic ... may be straining at gnats and swallowing camels. But if one is to swallow a camel, one may as well do so in a gnat-free atmosphere'.
} 
legitimate forms of historical inquiry, and a genuine analysis of the problems that they present will lead to an enriched understanding of both.

Christodoulou

G. A. Christodoulou (ed.), Tà óox $\alpha \tilde{i} \alpha \sigma \chi o ́ \lambda ı \alpha$

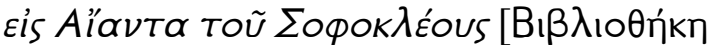

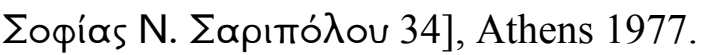

Merro

G. Merro (ed.), Gli scoli al Reso euripideo,

Orione: Testi e Studi di Letteratura Greca 2;

Messina 2008.

$P C G$

R. Kassel and C. F. L. Austin (eds.), Poetae

Comici Graeci, 8 vols., Berlin and New York 1983-2001.

Schwartz

E. Schwartz (ed.), Scholia in Euripidem, 2 vols., Berlin 1887-91.

Theodoridis

C. Theodoridis (ed.), Die fragmente des

Grammatikers Philoxenos [Sammlung

griechischer und lateinischer Grammatiker 2],

Berlin and New York 1976.

$\operatorname{Tr} G F$

Tragicorum Graecorum Fragmenta. Vol. 1

Didascaliae Tragicae, Catalogi Tragicorum et

Tragoediarum, Testimonia et Fragmenta

Tragicorum Minorum (ed. B. Snell, $2^{\text {nd }}$ ed. rev.

R. Kannicht; Göttingen $1971^{1}, 1986^{2}$ ); vol. 3

Aeschylus (ed. S. L. Radt; 1985); vol. 4 
Sophocles (ed. S. L. Radt; $1977^{1}, 1999^{2}$ ); vol. 5

Euripides, 2 parts. (ed. R. Kannicht; 2004).

Allan, W. (2008), Euripides. Helen, Cambridge.

Barrett, W. S. (1964) Euripides. Hippolytos, Oxford.

- (2007), Greek Lyric, Tragedy, and Textual Criticism. Collected Papers. Assembled and edited by M. L. West, Oxford.

Coo, L. M.-L. (2013), 'A Sophoclean slip: mistaken identity and tragic allusion on the Exter pelike', in: BICS 56, 67-88.

Csapo, E., and Slater, W. J. (1994), The Context of Ancient Drama, Ann Arbor.

Dawe, R. D. (2006). Sophocles. Oedipus Rex ${ }^{2}$, Cambridge. [1 ${ }^{\text {st }}$ edn 1982]

Falkner, T. (2002), 'Scholars versus actors: text and performance in the Greek tragic scholia', in: P. E. Easterling and and E. Hall (eds.), Greek and Roman Actors. Aspects of an Ancient Profession, Cambridge, 342-61.

Finglass, P. J. (2006), 'The interpolated curse', Hermes 134: 257-68.

- (2007), Sophocles. Electra [Cambridge Classical Texts and Commentaries 44], Cambridge.

- (2009), 'Sophocles' Tecmessa: characterisation and textual criticism', Eikasmos 20: 85-96.

- (2011), Sophocles. Ajax [Cambridge Classical Texts and Commentaries 48], Cambridge.

- (2012), 'The textual transmission of Sophocles' dramas', in: K. Ormand (ed.), The Blackwell Companion to Sophocles, Malden, MA, Oxford, Chichester, 924.

- (2013), 'Il valore dei papiri per la critica testuale di Sofocle', in: G. Bastianini and A. Casanova (eds.), I papiri di Eschilo e di Sofocle. Atti del convegno 
internazionale di studi, Firenze, 14-15 giugno 2012 [Edizioni dell'Istituto Papirologico “G. Vitelli” 2], Florence., 33-51.

— (2014a), 'A new fragment of Euripides' Ino', ZPE 189: 65-82.

— (2014b), 'Sophocles' Philoctetes 671-673: a reconsideration reconsidered', Mnemosyne $4^{\text {th }}$ ser. 67 (2014) 443-9.

- (2016), 'Papyri and the textual criticism of Greek authors', in: W. de Melo and S. Scullion (eds.), The Oxford Handbook of Greek and Latin Textual Criticism, Oxford 2016.

— (forthcoming), Sophocles. Oedipus the King.

Hall, E. M. (2007), 'Greek tragedy 430-380 BC', in: R. Osborne (ed.), Debating the Athenian Cultural Revolution. Art, Literature, Philosophy, and Politics 430380 BC (Cambridge), 264-87.

— (2010), 'Tragic theatre: Demetrios' rolls and Dionysos' other woman', in: O. Taplin and R. Wyles (eds.), The Pronomos Vase and its Context (Oxford), $159-79$.

Hamilton, R. (1974), 'Objective evidence for actors' interpolations in Greek tragedy', in: GRBS 15, 387-402.

Handis, M. W. (2013) 'Myth and history. Galen and the Alexandrian library', in: J. König, A. Oikonomopoulou, and G. Woolf (eds.), Ancient Libraries (Cambridge), 364-76.

Hutchinson, G. O. (1985), Aeschylus. Septem contra Thebas, Oxford.

Kovacs, D. (2003) 'Toward a reconstruction of Iphigenia Aulidensis', JHS 123: 77103.

— (2007) 'Tragic interpolation and Philip II: Pylades' forgotten exile and other problems in Euripides' Orestes', in: P. J. Finglass, C. Collard, and N. J. 
Richardson (eds.), Hesperos. Studies in Ancient Greek Poetry presented to M.

L. West on his Seventieth Birthday (Oxford), 259-75.

Lamari, A. A. (2010), Narrative, Intertext, and Space in Euripides' Phoenissae [Trends in Classics suppl. 6], Berlin and New York.

Marshall, C. W. (2004), 'Alcestis and the ancient rehearsal process (P. Oxy. 4546)', in: Arion $3^{\text {rd }}$ ser. $11 / 3,27-45$.

Mastronarde, D. J. (1994), Euripides. Phoenissae [Cambridge Classical Texts and Commentaries 29], Cambridge.

Meccariello, C. (2014), 'The opening of Euripides' Phoenissae between anecdotal and textual tradition', ZPE 190: 49-56.

Millis, B. W., and Olson, S. D. (2012), Inscriptional Records for the Dramatic Festivals in Athens. IG II'2318-2325 and Related Texts, Leiden and Boston.

O’Connor, J. B. (1908), Chapters in the History of Actors and Acting in Ancient Greece [Diss. Princeton], Chicago.

Page, D. L. (1934) Actors' Interpolations in Greek Tragedy Studied with Special Reference to Euripides' Iphigeneia in Aulis, Oxford.

- (1938) Euripides. Medea, Oxford.

Parker, L. P. E. (2007) Euripides. Alcestis, Oxford.

Pinto, P. M. (2013) 'Men and books in fourth-century BC Athens', in: J. König, A. Oikonomopoulou, and G. Woolf (eds.), Ancient Libraries, Cambridge, 85-95.

Revermann, M. (2006), Comic Business. Theatricality, Dramatic Technique, and Performance Contexts of Aristophanic Comedy, Oxford.

Scodel, R. (2007), 'Lycurgus and the state text of tragedy', in: C. Cooper (ed.), Politics of Orality [Mnemosyne suppl. 280], Leiden and Boston, 129-54. 
Taplin, O. P. (2007), Pots and Plays. Interactions between Tragedy and Greek VasePainting of the Fourth Century B.C., Los Angeles.

Vahtikari, V. (2014) Tragedy Performances outside Athens in the Late Fifth and the Fourth Centuries BC (Papers and Monographs of the Finnish Institute at Athens 20; Helsinki).

West, M. L. (1987), Euripides. Orestes, Warminster.

Willink, C. W. (1986), Euripides. Orestes, Oxford.

— (1988) 'Euripides, Medea 1-45, 371-85', CQ NS 38: 313-23. [=(2010) 116-31]

- (2010) Collected Papers on Greek Tragedy, ed. W. B. Henry, Leiden and Boston.

Zuntz, G. (1965), An Inquiry into the Transmission of the Plays of Euripides, Cambridge.

P. J. Finglass is Professor of Greek and Head of the Department of Classics at the University of Nottingham. He has published editions of Stesichorus (2014), Sophocles' Ajax (2011) and Electra (2007), and Pindar's Pythian Eleven (2007) with Cambridge University Press. 